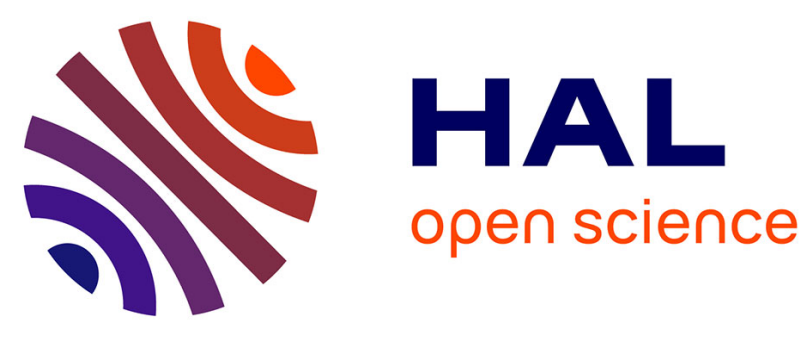

\title{
Traceability and Risk Management in Multi-modal Container Transport: A Small - Scale Review of methods and technologies
}

Cheik Aboubakar Ouedraogo, Sina Namakiaraghi, Cedric Rosemont, Aurelie Montarnal, Matthieu Lauras, Didier Gourc

\section{To cite this version:}

Cheik Aboubakar Ouedraogo, Sina Namakiaraghi, Cedric Rosemont, Aurelie Montarnal, Matthieu Lauras, et al.. Traceability and Risk Management in Multi-modal Container Transport: A Small - Scale Review of methods and technologies. GOL'20 - The 5th edition of the IEEEE International Conference on Logistics Operations Management, Oct 2020, Rabat, Morocco. 8 p., 10.1109/GOL49479.2020.9314760 . hal-02985517

\section{HAL Id: hal-02985517 https://imt-mines-albi.hal.science/hal-02985517}

Submitted on 7 Dec 2020

HAL is a multi-disciplinary open access archive for the deposit and dissemination of scientific research documents, whether they are published or not. The documents may come from teaching and research institutions in France or abroad, or from public or private research centers.
L'archive ouverte pluridisciplinaire HAL, est destinée au dépôt et à la diffusion de documents scientifiques de niveau recherche, publiés ou non, émanant des établissements d'enseignement et de recherche français ou étrangers, des laboratoires publics ou privés. 


\section{Traceability and Risk Management in Multi-modal Container Transport: A Small - Scale Review of methods and technologies}

\author{
$1^{\text {st }}$ Cheik Aboubakar OUEDRAOGO \\ Université de Toulouse \\ IMT Mines Albi-Carmaux \\ Albi, France \\ cheik.ouedraogo@mines-albi.fr
}

\author{
$2^{\text {nd }}$ Sina Namakiaraghi \\ Université de Toulouse \\ IMT Mines Albi-Carmaux \\ Albi, France \\ sina.namakiaraghi@mines-albi.fr
}

\author{
$3^{\text {rd }}$ Cedric ROSEMONT \\ Maritime Transport \\ Next4 \\ Toulouse, France \\ contact@next4.io
}

\author{
$4^{\text {th }}$ Aurélie Montarnal \\ Université de Toulouse \\ IMT Mines Albi-Carmaux \\ Albi, France \\ aurelie.montarnal@mines-albi.fr
}

\author{
$5^{\text {th }}$ Matthieu Lauras \\ Université de Toulouse \\ IMT Mines Albi-Carmaux \\ Albi, France \\ matthieu.lauras@mines-albi.fr
}

\author{
$6^{\text {th }}$ Didier Gourc \\ Université de Toulouse \\ IMT Mines Albi-Carmaux \\ Albi, France \\ didier.gourc@mines-albi.fr
}

\begin{abstract}
Increasing flexibility and responsiveness are the opportunities that smart logistics offers to companies. With the development of the supply chain network (SCN) and big data processing, a simple view at above two technologies separately has become unadvisable. This work deals with the traceability and supply chain risk management of containers during shipping expeditions using real-time Data. The main objective of this article is to analyse proposed solutions to improve the efficiency of the supply chain by acting on risk management in containers transport. A future approach to improve the real-time management of shipments by taking into account random events is mentioned.
\end{abstract}

Index Terms-Smart Container, Traceability, Internet of Things, Supply chain risk management

\section{INTRODUCTION}

Multi-modal shipment is one of the key factors of globalization. $90 \%$ of world trade is carried by sea transport [1] and $80 \%$ of the goods transported by vessel are actually transported in containers [2]. This shows the influence of container shipment on the international trade and multimodal transport. Fremont et al [3] sums it up all when claiming that without maritime transport and containerization, there is no globalization possible. However, container transport faces a large number of social problems such as [4]:

- Transport of sensitive materials (cold chain, chemicals, nuclear) that requires special conditions of transport to avoid any risk.

- Lack of visibility during container multi-modal transport. In fact knowing the position and shipment conditions of containers during shipping permit to avoid theft, deterioration of goods and delays impacting all supply chain.

- Difficulty to find fast and safe roads ensuring supply chain efficiency while reducing the carbon footprint.
Most of the companies do not have a structured framework to manage and mitigate their supply chain risks in container multi-modal transport [5]. To increase their flexibility and responsiveness to the growing demand, 90\% of logistics and transport companies are moving towards smarter logistics using Internet of Things (IoT) solutions. The IoT offers new possibilities in terms of visibility and permits to increase the performance of the supply chain based on the amount of data gathered. The development of internet of things permits to track containers by using Intelligent tracking technologies. A large number of technological and scientific solutions have been developed to track and trace containers in order to deal with these problems. The main objective of this article is to analyze scientific methods, technologies and industrial solutions proposed to ensure traceability, security and integrity of containers during the shipment in order to define a better methods for the container supply chain risk management.

This work consists in three stages, the first of which aims to define the context and problems that are faced in the container multi-modal container transport. The second will present scientific works, projects and industrial solutions proposed to deal with the problems mentioned in section one. Then the efficiency and effectiveness of the solutions will be discussed, and a first direction is given to address the problems of real-time data collection and exploitation to help managing containers transport and its related hazards in last section.

\section{ConteXt}

Container transport gains more and more concern [6]. Stakeholders involved in multi-modal shipment, whether shippers, forwarders, logistic companies or customers, agree on the need to develop some related functions around container supply chain risk management in order to take proactive actions. Surveys 
that have been carried out as part of the projects to improve transport performance and goods security have identified needs around supply chain management and risk management. This work shows that technological advance permits to go further in the implementation of methods and development of innovative solutions in order to better deal with risk management and improvement of supply chain in container shipment.

\section{A. Features around Supply Chain Management}

According to Lee et al (1993), "Supply chain is a network of facilities that assures the functions of supply of raw materials, transformation of these raw materials into components and finished products, and distribution of finished products to customers". Supply chain management is the management of all operations related to the supply chain, which take account flow management(physical and information), inventory management and supplier management. In the field of maritime transport, it is consist of putting in place actions ensuring the quality and the safety of the goods during all the duration of the transport. To ensure quality and safety during container multi-modal shipment, supply chain management must fill the following features (Fig 1):

- Master the expeditions by promoting the automatic feedback of tracking and monitoring data ( [7]-[9] );

- Generate alerts to warn supply chain actors of abnormal events so that they can make proactive decisions( [6], [9] );

- Do analytics to improve decision-making through an analysis of data collected during expeditions;

- Do prediction to detect hazards through predictive analysis and to suggest avoidance plans dynamically.

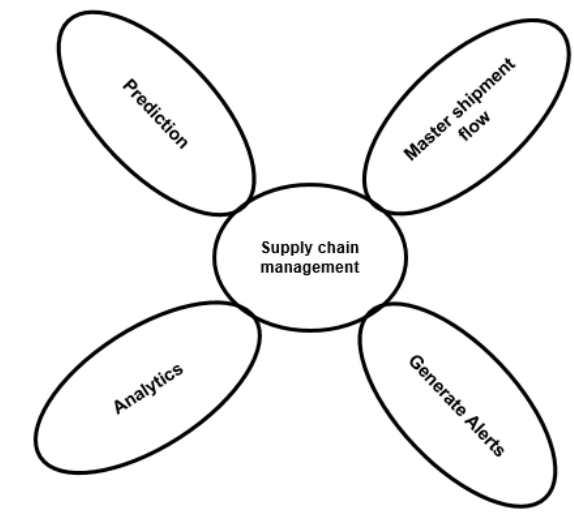

Fig. 1. Features around Supply Chain Management.

\section{B. Features around Risk Management}

According to ISO standard on risk management vocabulary, risk management is the "coordinated activities to direct and control an organization with regard to risk" [10]. And the risk is defined as an effect of uncertainty on objectives, with an effect defined as "a deviation from the expected" [11]. Supply chain risk management is defined as "the identification of potential sources of risk and implementation of appropriate strategies through a coordinated approach among supply chain members to reduce supply chain vulnerability" [12]. In container transport case, risk management is to deploy a set of avoidance measures for identified risks upstream or taking palliatives or corrective solutions during transport to ensure the safety and integrity of the container and the transported goods. The work done by J. Scholliers et al [13] has identified the features that risk management needs to cover in maritime transport ( Fig2 ):

- Identify Risk: Risk identification helps to identify the future uncertainties and potential risk surrounding the supply chain [7];

- Evaluate Risk by using the tracking and monitoring data, the extent of the threats will be evaluated ( [4], [7], [14]). It has three types of impact for maritime supply chain: time-based, finance-based and quality-based [5];

- Treat Risk by taking measures of prevention and avoidance ( [4], [7], [14]).

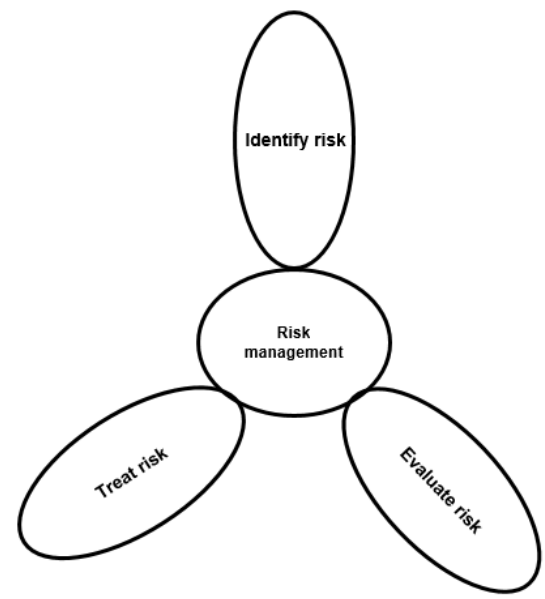

Fig. 2. Features around Risk Management.

These functions have already been the subject of major research projects in recent years that have given rise to scientific methods and commercial solutions. Most of the works done in recent years focus in abilities to predict the occurrence of risks and mitigate their negative effects by using qualitative and quantitative methods [15]. However just few of them take real-time data in consideration and dynamically suggest risk avoidance plans.

So the question that arises is how to use the advanced technological and scientific work to improve in real-time supply chain risk management in multi-modal container transport by predicting random events during expeditions?

\section{Research Methodology}

To carry out this study the most important concepts have been translate to keywords. This helped to identify keywords such as Smart Container, Traceability, Internet Of Things, Estimated Time Arrival and Supply chain risk management related to 
multimodal maritime container shipment. As the objective of the study is to capture scientific works and industrial solutions, we have done a bibliographic research on major scientific databases such as Scopus, Web of science and google scholar in order to find articles and projects that is less than five years old on the subject. Then we discarded the results that did not focus on multi-modal maritime supply chain risk management. This allowed us to select 42 articles that deal with scientific methods, frameworks and technologies proposed to overcome with the problems of container shipment. We also carried out a small benchmark on ten major companies offering a container tracking solution in order to identify industrial solutions proposed in present day to overcome the problem of container traceability and risk management in maritime transport.

\section{TRACEABILITY IN MARITIME TRANSPORT}

\section{A. Definition of traceability}

According to ISO 9000-2005, traceability is defined as "the ability to determine the history, use or location of a specific entity". Definition of traceability depends on the studies context [16]. Thus, in this paper, traceability will define as the ability to follow and monitor container movements and trace back information from its internal and external environment.

\section{B. Technologies used}

Container inside environment need to be monitored in order to ensure better supply chain management and risk management during the shipment [13]. Containers traceability can be performed using different technologies depending on the needs and interests of the stakeholders in the supply chain. This technologies include global positioning systems (GPS), geographic information systems (GIS), wireless telecommunications, and radio frequency identifcation (RFID) and Blockchain [17]. Overall the technology used in container traceability has not changed much since 2013, innovation comes from the contribution of functionality by combining these technologies and scientific research in order to improve supply chain risk management. The research made by G. Schilk et al [18] and H. Jacquemoud et al [19] made it possible to draw up Table I.

TABLE I

TECHNOLOGIES USED

\begin{tabular}{|c|c|c|}
\hline Technology & Advantages & Disadvantage \\
\hline GPS & Good outdoor accuracy & $\begin{array}{c}\text { Interdependent system } \\
\text { (GPS, Glonass or Galileo) }\end{array}$ \\
\hline GSM & Highly developed telephony & $\begin{array}{c}\text { Precision related to Antennas } \\
\text { density, System } \\
\text { interdependent to telecoms } \\
\text { networks }\end{array}$ \\
\hline Wi-Fi & $\begin{array}{c}\text { Good precision , } \\
\text { uses the existing network } \\
\text { Transport of information }\end{array}$ & $\begin{array}{c}\text { Coverage area to be established. } \\
\text { Calibration }\end{array}$ \\
\hline GPRS & Passive tag & $\begin{array}{c}\text { Receiver deployment } \\
\text { depending on the project. } \\
\text { Dedicated infrastructure }\end{array}$ \\
\hline Sensors & $\begin{array}{c}\text { Fonit connection } \\
\text { Always on }\end{array}$ & $\begin{array}{c}\text { Dependent to GSM } \\
\text { Returns real-time Data }\end{array}$ \\
\hline
\end{tabular}

\section{LITERATURE REVIEW}

The table II combines different methods identified in the research (scientific methods, projects and industrial solutions) with the different functionalities identified in supply chain management and risk management.

\section{A. Scientific methods and solutions}

The study led to identify methods and technologies used to ensure tracking, security and risk management of containers during the shipment. First we will present the scientific methods proposed in the literature, then we will discuss the scientific projects conducted in this context and finally we will mention the proposed industrial solutions.

1) Scientific methods and solutions for supply chain management:

a) Artificial Intelligence:

- Machine learning There are many studies using Artificial neural-network (ANN) approaches to estimate travel time. Machine learning tools have ability to learn the system's behaviour with training data-sets. ANN is a subset of machine learning. It tries to mimic the human brain model, each neuron receiving input signals and providing an output signal depending on the processing function used. We talk about artificial neural-network when we use many neurons to get output signal [32].

- Multi-agent systems (MAS): A Multi-Agent System (MAS) has several agents that interact with each other in a common environment. Some of these agents can be people or their representatives, or even mechanical machines. And an agent is defined as an entity capable of taking actions alone or in coordination with other agents in order to achieve a goal [20]. In MAS, agents use their interactions with neighbouring agents or with the environment to learn new contexts and actions. This model can be used to improve cooperation and information sharing between maritime transport stakeholders [22].

b) Simulation: Simulation is used to build a virtual supply supply chain and to evaluate potential risk impacts. Many studies use Agent-Based Simulation, Discrete Event Simulation , Monte Carlo Simulation, and System Dynamics Simulation to test risk scenarios in supply chain in order to create avoidance plan. For example, Mulyati and Geldermann [33] applied the Delphi method to analyze potential risks, and multi-criteria decision analysis to evaluate mitigation strategies. Simulation technique is used to process Data in order to make analytical prediction in the impact of risk events in supply chain [22].

c) Search Algorithms: This kind of algorithms are used to find optimizes routes for container transport [22]. The majority of algorithms are used to build a decision support system (DSS). A common definition of DSS is that it's a computer program use to help companies to make better decisions based on data processing. In their paper, [8] propose a model based in decision support system architecture and radio frequency identification (RFID) in order to handle production monitoring and scheduling in a distributed manufacturing environment 
TABLE II

PROPOSED SOLUTIONS ASSOCIATED WITH FEATURES

\begin{tabular}{|c|c|c|c|c|c|}
\hline Features & Functions & Scientifical Work & Projects & Insdutrials solutions & Companies \\
\hline \multirow[t]{4}{*}{$\begin{array}{l}\text { Arround Supply } \\
\text { Chain Management }\end{array}$} & $\begin{array}{l}\text { Master flow of shippement } \\
\text { in real-time }\end{array}$ & $\begin{array}{l}\text { - Multi-agent system [7], [20], [20] } \\
\text { - Simulation [7], [21] } \\
\text { - Artificial Neural Network [22] } \\
\text { - Search algorithm [22] } \\
\text { - River Information Services [18] } \\
\text { - Internet of thing [17] } \\
\text { - Blockchain }\end{array}$ & $\begin{array}{l}\text { - TradeLens Blockchain [23] } \\
\text { - Shipping Solution [23] } \\
\text { - UPS Blockchain Tracking [23] . }\end{array}$ & $\begin{array}{l}\text { - Cyber-Physical Systems, } \\
\text { - Transport Management System } \\
\text { (TMS) [24] } \\
\text { - Entrprise ressource planning } \\
\text { (ERP) [24] }\end{array}$ & $\begin{array}{l}\text { - Next4 [25] } \\
\text { - Traxens [26] } \\
\text { - Schenker [27] } \\
\text { - Arviem [28] } \\
\text { - StarCom [29] }\end{array}$ \\
\hline & Generate Alerts & $\begin{array}{l}\text { - Decision support [4] } \\
\text { - River Information Services [18] }\end{array}$ & $\begin{array}{l}\text { - TradeLens Blockchain [23] } \\
\text { - Luggage tracker Shipping [23] } \\
\text { Solution } \\
\text { - UPS Blockchain Tracking [23] }\end{array}$ & $\begin{array}{l}\text { - Cyber-Physical Systems } \\
\text { - TMS [24] }\end{array}$ & $\begin{array}{l}\text { - Next4 [25] } \\
\text { - Traxens [26] } \\
\text { - Schenker [27] } \\
\text { - Arviem [28] } \\
\text { - StarCom [29] }\end{array}$ \\
\hline & Do Analytics & $\begin{array}{l}\text { - Big Data [30] } \\
\text { - Data mining [30] } \\
\text { - Fault-tree analysis }\end{array}$ & $\begin{array}{l}\text { - Cyber-Physical Systems [13] } \\
\text { - Business Intelligent (BI) }\end{array}$ & $\begin{array}{l}\text { - Cyber-Physical Systems [13] } \\
\text { - TMS [24] }\end{array}$ & - Arviem [28] \\
\hline & Do Prediction & $\begin{array}{l}\text { - Simulation [7], [21] } \\
\text { - Prediction Algorithm [31], } \\
\text { - Machin learning [31] }\end{array}$ & $\mathrm{X}$ & - Cyber-Physical Systems [13] & $\mathrm{X}$ \\
\hline \multirow[t]{3}{*}{ Arround Risk Management } & Identify Risk & $\begin{array}{l}\text { - Formal safety Assement(FSA) [12] } \\
\text { - Faillure Mode and effect analyse } \\
\text { (FMEA) [12], } \\
\text { - AMDEC, }\end{array}$ & - GOST [9] & $\begin{array}{l}\text { - Tracking devices [17] } \\
\text { - Smart Storage Containers } \\
\text { project, }\end{array}$ & $\begin{array}{l}\text { - Next4 [25] } \\
\text { - Traxens [26] } \\
\text { - Schenker [27] } \\
\text { - Arviem [28] } \\
\text { - StarCom [29] }\end{array}$ \\
\hline & Evaluate Risk & $\begin{array}{l}\text { - Fault-tree analysis [30], } \\
\text { - FSA [12] } \\
\text { - FMEA [12] }\end{array}$ & - Smart Storage Containers project & - Tracking devices [17] & - Arviem [28] \\
\hline & Treat Risk & $\begin{array}{l}\text { - Simulation [7], [21] } \\
\text { - Agent base [7], } \\
\text { - Decision support framework }\end{array}$ & $\begin{array}{l}\text { - AgriBlockIoT project [23] } \\
\text { - GOST [9] }\end{array}$ & - Cyber-Physical Systems & $\mathrm{X}$ \\
\hline
\end{tabular}

[22]. The use of DSS permits to improve efficiency of supply chain by helping to find optimize routes and reacting quickly in case of events which make the transportation plan infeasible.

d) Cloud Computing and Internet of Things(IOT): Cloud computing offers unlimited data storage space to collect the information provided by the IOT. The survey shows that few research use cloud computing technology and smart device (IoT) to track and collect data during container transport [8], [23], [34].

e) Data Science: Data science is the application of quantitative and qualitative methods to solve relevant problems and predict outcomes [30]. For example Mani et al explore the advantages of using Data Science in supply chain management and show that practitioners using Big data Analytic tools build sustainable supply chains [35], [36]. Predictive analytic is a subset of data science which permit to improve supply chain efficiency by estimating past and future.

f) River Information Services: River Information Services (RIS) are the information technology (IT) designed to optimize traffic and transport processes in inland navigation. The objectives of RIS are:

- Enhancement of inland navigation safety in ports and rivers [21];

- Provision of local and regional traffic information for safety monitoring on tactical as well as strategical level [21];

- Information on fairways to plan, execute and monitor voyages by boat masters and fleet managers (e.g. water levels, traffic signs, and opening hours of locks). The information systems contain geographical, hydrological and administrative data for this purpose [21].

RIS permits to improve transport planning and management process along multi-modal transport chain.
2) Scientific methods and solutions for Risk Management: Tixier et al [37] proposed an extensive review of risk analysis methodologies used in industrial plants. These methodologies are classified into two groups: qualitative and quantitative. Each group is divided into three categories (deterministic, probabilistic and the combination of both). This research reveals the existence of 62 risk analysis methodologies, each one following a risk management framework to define the strategy that permits to mitigate the corresponding risk. Mostly time mitigation strategy is composed of:

- Risk identification ( [4], [5], [21]);

- Risk evaluation and qualification ( [4], [5], [21]);

- Risk mitigation ( [4], [5]);

- Risk monitoring ( [38], [39]).

And mixed approach are the methods used to treat different items identity in risk management framework.

a) Framework for risk management in real time: Most of the frameworks have been created to guide the risk management phases, as well as, support risk methodological approaches but aren't integrate real time data, Just two of them until now use real time data to mitigate risk. Güller et al [7] developed an Agent-based Simulation framework which comprises data management/data source; supply chain visualization and detection; simulation and prevention stages. More recently Wattanakul et al proposed a framework to identify in real time disruption and root cause of disruption during container shipment due to traceability data and route plane [34].

b) Mixed approaches for risk management: J.B. Oliveira and al [21] explored the solution approaches in risk management in literature and they highlight mixed-approach using simulation and optimization methods to analyse and evaluate potential risks: 
- Integer Linear Programming, and Linear Programming optimization techniques [21];

- Integer Programming models, stochastic approaches, and robust optimization [21];

- Particle Swarm Optimization, Genetic Algorithms, Neural Networks, and Simulated Annealing [21].

c) Formal Safety Assessment(FSA): The International Maritime Organization (IMO) defines Formal Safety Assessment as a process used for assessing risks and protect the environment in maritime area in order to increase the safety. FSA consists of five steps:

- Identification of risk events [40];

- Assessment of risks (estimate risk impact) [40];

- Risk control options (reduce risk occurrence by using avoidance plan) [40];

- Cost benefit assessment (determining cost effectiveness of each risk control option);

- Suggest decisions (suggest measure to control risk and avoid losses) [40].

d) Faillure Mode and Effect Analyse: Faillure Mode and Effect Analyse (FMEA) is a method used for risk events identification and risk analysis. The FMEA method has three attributes(namely failure occurrence likelihood, consequence severity, and probability of failures being undetected that are employed to assess the safety level of a failure [12]. The method has been mixed with advanced uncertainty modelling techniques such as fuzzy sets, grey theory to enable it's practical applications in maritime safety [41].

e) Fault-tree Analysis: Fault-tree analysis is a tool used for risk analysis in complex system. This method is used to find risk occurrence and potential causes in supply chain. Fault-trees are helpful in analyzing different ways in which a particular failure can occur and the probability of its occurrence [30].

\section{B. Project}

In their article A. MOHAMED et al entitled Traceability in logistic chains using IoT and Blockchain [23] makes a state of the art of major industrial projects and technologies used to ensure container traceability.

The TradeLens Blockchain Shipping Solution project is a collaborative project between Maersek and IBM to track container during shipment. Tradelens platform use blockchain for traceability [23].

The UPS Blockchain Tracking Solution project is a UPS project for tracking package during transport by using blockchain technology [23].

The project Luggage tracker is a collaboration project between Louis Vuitton and Sigfox to integrate a tracking device in some high cost luggage. This device use RFID technology [23].

The Smart Storage Container project is a project to develop a prototype of intelligent container in order to improve supply chain traceability by using IoT combined with a blockchain technology [23].
The AgriBlockIoT project use IoT and blockchain to create a transparent, by tracking supply chain actions in the agrifood sector [23].

The GOST (Geolocation, Optimization, Container Transport Security) project is a project that uses an inter-mediation platform coupled with technological solutions enabling the tracking and securing of container transport. The objective was to create cyber-physical system that permit to ensure secutity and traceability of hazardous material transport [9].

More details can be found in [23].

\section{Industrial solution}

The majority of the solutions identified in literature is based on the IoT and web service technologies to ensure the tracking and safety of the goods shipped. There are mainly two types of solutions, the one proposed by the shipowners and the one proposed by the tracking companies.

1) Solution proposed by shipowners: The largest ship owners who offer an online tracking solution for the containers they carry. Thanks to Electronic Data Interchange (EDI) and the Automatic Identification System (AIS), the shipowners are able to calculate with some accuracy the exact location of a container. The EDI permits to improve communication between stakeholders in maritime area by giving real-time data transfer standard. This allows to create a web-EDI that gives the container location by using container identification number [42] The Automatic Identification System (AIS) is an automatic tracking system used as a tool to increase the navigation safety and efficiency as well as vessel traffic management [43].

2) Solution proposed by tracking companies: Among the solutions proposed by tracking companies, we distinguish Transport Management System (TMS) and smart container.

a) Transport Management System: A Transport Management System is a tool that help to manage transport. The TMS mainly addresses the needs of traceability of deliveries and optimization of transport (schematics and assignment of carriers) and makes it possible to improve the organization of the transport. These improvements translate into a reduction in the transport budget [24]. The main features of TMS are:

- Optimization engine (Load and Route) ( [24], [44]);

- Real-time tracking ( [24], [44]);

- Carrier contracts management ( [24], [44]);

- Reports and Business Intelligence ( [24], [44]).

b) Smart container: It seems important to introduce the concept of smart product (SP) before talking about the smart container.

According to McFarlane the concept of SP covers the physical and informational representation of a product. It is characterized by a unique identifier, communication with the environment, information gathering, the deployment of a language for the communication of its characteristics, and the ability to make decisions [39].

The definition proposed by Kärkkäinen et al. [45] focuses on the SP's ability to make decisions. Thus, the SP must have a unique identifier. It must share its information, either in the form of accessible sources, or include them in its identifier. And 
finally, the SP must be able to communicate with information systems and users as needed [39].

Ventä [46] focused on the SP's ability to perceive its environment and react to changes in order to maintain a performance threshold. According to Ventä, the SP must constantly monitor its state and its environment. It must also react and adapt to environmental and operational conditions. The SP must maintain optimal performance under varying circumstances, also in exceptional cases. Finally, the SP must actively communicate with users, the environment or with other products and systems [39].

Starting from these three definitions, a smart product can be characterize by its ability to identify, collect and transmit the information of its environment and must be able to adapt according to the variations to keep optimal performances. The concept of smart container has been put in place to overcome the traceability problem encountered in the transport of containers. Indeed the knowledge of the paths and the real-time position of the container allows to protect against theft, loss and other incidents of containers. Building a smart container means using technological and scientific advances to ensure traceability and safety of container. The smart container was created to overcome the problems of linking to the supply chain and to enable better risk management in supply chain. For this, we have identified features that the smart container must answer.

The solutions offered by tracking companies are more reliable in terms of geolocation and they also offer the advantage of monitoring the environment of containers. We find especially on the market:

- Electronic seals (e-seals) mostly used to have container door status [11].

- Tracking devices, used to get the container traceability. These devices give information related to container localization and container inside environment such as temperature, humidity, light, pressure and shock [17].

- Container Security Devices, that associate tracking devices and intrusion detectors [11].

This introduces the notion of smart container and smart Logistics in order to adapt flexibly and quickly on the basis of increased availability of information. Comments on the five most innovative solutions are currently proposed are presented in the table III.

\section{REVIEW AND RECOMMENDATION}

All the research carried out in the field of container traceability and risk management shows that the subject has been the object of extensive research and projects aimed at improving the security, safety and real-time monitoring of containers during shipments and container terminals. IOT have made it possible to have better visibility in port operation and multi-modal container transport. Research also shows the existence of solutions in terms of supply chain optimization and risk management based on artificial intelligence [47], big data [35], [36], simulation [7] and IOTs [48]. However just few of these methods integrate real-time data in their process [7],
TABLE III

TRACKING SOLUTIONS

\begin{tabular}{|c|c|c|c|}
\hline Company & Location & Technologies & Features \\
\hline Next4 [25] & $\begin{array}{c}\text { Toulouse, } \\
\text { France }\end{array}$ & $\begin{array}{c}\text { GSM, } \\
\text { LTE-M, GPS }\end{array}$ & $\begin{array}{c}\text { Postioning,Shocks, } \\
\text { door open/close, } \\
\text { Container movement, } \\
\text { Temperature and } \\
\text { humidity } \\
\text { variation, Crane liftup }\end{array}$ \\
\hline Traxens [26] & $\begin{array}{c}\text { Marseille, } \\
\text { France }\end{array}$ & GSM, GPS & $\begin{array}{l}\text { Shocks, door open/close, } \\
\text { Container movement, } \\
\text { Temperature and humidity } \\
\text { variation }\end{array}$ \\
\hline Schenker [27] & Germany & $\begin{array}{l}\text { GSM, GPS } \\
\text { GPRS }\end{array}$ & $\begin{array}{c}\text { Real time tracking, } \\
\text { door open/close, } \\
\text { Container movement, } \\
\text { Temperature and } \\
\text { humidity variation } \\
\end{array}$ \\
\hline Arviem [28] & Switzerland & GSM, GPS, satellite & $\begin{array}{c}\text { Real time tracking, } \\
\text { door open/close, } \\
\text { Container movement, } \\
\text { Temperature and } \\
\text { humidity variation, } \\
\text { analytics tools, } \\
\text { carbon footprint }\end{array}$ \\
\hline StarCom [29] & $\begin{array}{l}\text { Jerjey, } \\
\text { USA }\end{array}$ & $\begin{array}{l}\text { GSM, HSDPA, } \\
\text { GPS,GLONASS }\end{array}$ & $\begin{array}{c}\text { Postioning, door open/close, } \\
\text { Container movement, } \\
\text { Temperature and humidity } \\
\text { variation } \\
\text { (On Hybrid device only) }\end{array}$ \\
\hline
\end{tabular}

[34]. Thanks to various technological advances, commercial solutions ensuring container tracking have been proposed. These solutions help to monitor containers environment and send reactive alerts on the events during the transit. But theses solutions find their limits in terms of doing analytical processing of data and prediction in transport condition. e.g, many of solutions fail to estimate correctly time of arrival and suggest optimal routes by taking random events into account. New Predictable Risk Management Approach by using historical and real-time Data in Container Transport is necessary. Indeed, in their paper, L. Landers [17] show the need of integration of real time data in decision making in risk management process, by arguing in the fact that the utilization of real-time data can provide instantaneous decision-making responses to variations in the supply chain. Communication throughout the supply chain is of foremost importance in order for decision-making to be truly responsive to events [17]. On this basis, Mr Güller et al [7] proposes a framework for the design of a simulationbased decision support system for the real-time management of disruptions and mitigation of risks in supply chains, in the same way Zou and al [48] introduce a new method, which uses field programmable gate array (FPGA) to design embedded device to execute related algorithms in parallel for underling data processing to reduce risks which caused by time-delay in supply chain network (SCN) and wattanakul et al [34] proposed a framework using historical and real-time data to improve the responsiveness to disturbances of the supply chain and to develop robust scheduling in container shipping. In addition Andziulis et al [49] design a real-time mobile cargo monitoring system integrate RFID and sensor in order to increase intermodal container transportation mobility, safety and overall effectiveness. 


\section{CONCLUSion AND Future Work}

This small scale scientific literature review was conducted to propose the state of art of technologies and solutions (scientific and industrial) in the field of multi-modal container supply chain risk management. We observed that many research used AI techniques, multi-agent systems and simulation to build decision support system in order to optimize supply chain risk management but just few of them integrate real-time data gathered with traceability units. We also noted that nearly $90 \%$ of companies from logistics transport sector have already implemented or will implement IoT solutions in order to increase customer requirements. The aims of this work is to show the real need to integrate real time data in supply chain risk management in order to be more reactive and proactive in decision making. In fact, predictive risk management will help supply chain stakeholders to be more reactive to disruption and to make proactive mitigating decisions by taking into account the possible occurrence of risks. It will therefore be relevant to focus on a AI technique for predicting random events during shipments of goods to ensure effective risk management within the supply chain. To overcome of limitations identified in literature, future work will be conducted to answer this following questions:

1) What is the most current risks present in container multimodal transport supply chain?

2) How we can identify with good accuracy this risks using traceability data and data science analytic tools?

3) What methods is better to address this risks by using preventive or mitigation measures?

\section{ACKNOWLEDGMENT}

I would like to thank the company Next4 for its collaboration in this research work. Next4 is a French company specializing in the design and manufacture of trackers for containers.

\section{REFERENCES}

[1] Conteneurs intelligents l'exploitation en temps reel des donnees de conteneurs intelligents. [Online]. Available: http://www.unece.org/unece/ search $q \mathrm{q}=$ Smart+container\&op=Search

[2] Transport maritime conteneurisé et mondialisation | cairn.info. [Online]. Available: https://www.cairn.info/ revue-annales-de-geographie-2005-2-page-187.htm

[3] A. Frémont, "Le transport maritime depuis 1945 : facteur clé de la mondialisation," vol. $\mathrm{n}^{\circ}$ 94, no. 1, pp. 16-29. [Online]. Available: https //www.cairn.info/revue-entreprises-et-histoire-2019-1-page-16.htm

[4] M. Abdel-Basset, M. Gunasekaran, and N. Chilamkurti, "A framework for risk assessment, management and evaluation: Economic tool for quantifying risks in supply chain," vol. 90.

[5] J. Vilko, P. Ritala, and J. Hallikas, "Risk management abilities in multimodal maritime supply chains: Visibility and control perspectives," vol. 123, pp. 469-481. [Online]. Available: https: //linkinghub.elsevier.com/retrieve/pii/S0001457516304031

[6] S. B. Xu, "Secure and smart container research based on the internet of things," vol. 687-691, pp. 2485-2489. [Online]. Available: https://www.scientific.net/AMM.687-691.2485

[7] M. Güller, E. Koc, T. Hegmanns, M. Henke, and B. Noche, "A simulation-based decision support framework for real-time supply chain risk management," vol. 4, no. 1, pp. 17-26. [Online]. Available: https://doi.org/10.1080/2287108X.2015.1008948
[8] Z. X. Guo, E. W. T. Ngai, C. Yang, and X. Liang, "An RFID-based intelligent decision support system architecture for production monitoring and scheduling in a distributed manufacturing environment," vol. 159, pp. 16-28. [Online]. Available: http: //www.sciencedirect.com/science/article/pii/S0925527314002825

[9] Géolocalisation, optimisation, sécurisation du transport de conteneurs. [Online]. Available: http://isidoredd.documentation. developpement-durable.gouv.fr/documents/Temis/0076/Temis-0076307/ 2030.pdf

[10] definition de supply chain management. [Online]. Available: https://www.glossaire-international.com/pages/tous-les-termes/ supply-chain-management.html

[11] 14:00-17:00. ISO guide 73:2009. [Online]. Available: http://www.iso.org/ cms/render/live/en/sites/isoorg/contents/data/standard/04/46/44651.html

[12] H. Alyami, Z. Yang, R. Riahi, S. Bonsall, and J. Wang, "Advanced uncertainty modelling for container port risk analysis," vol. 123, pp. 411-421. [Online]. Available: https://linkinghub.elsevier.com/retrieve/pii/ S0001457516302858

[13] J. Scholliers, A. Permala, S. Toivonen, and H. Salmela, "Improving the security of containers in port related supply chains," vol. 14, pp. 1374-1383. [Online]. Available: http://www.sciencedirect.com/science/ article/pii/S2352146516302125

[14] G. J. Lim, J. Cho, S. Bora, T. Biobaku, and H. Parsaei, "Models and computational algorithms for maritime risk analysis: a review," vol. 271, no. 2, pp. 765-786. [Online]. Available: https://doi.org/10.1007/s10479-018-2768-4

[15] G. Baryannis, S. Dani, and G. Antoniou, "Predicting supply chain risks using machine learning: The trade-off between performance and interpretability," vol. 101, pp. 993-1004. [Online]. Available: http://www.sciencedirect.com/science/article/pii/S0167739X19308003

[16] Elaboration d'une approche de trac,abilite dans le secteur forestier canadien. [Online]. Available: http://www.imo.org/fr/OurWork/Safety/ SafetyTopics/Pages/FormalSafetyAssessment.aspx

[17] A. Brewer, N. Sloan, and T. Landers, "Intelligent tracking in manufacturing," vol. 10 , pp. 245-250.

[18] G. Schilk and L. Seemann, "Use of ITS technologies for multimodal transport operations - river information services (RIS) transport logistics services," vol. 48, pp. 622-631. [Online]. Available: http://www.sciencedirect.com/science/article/pii/S1877042812027760

[19] H. Jacquemoud, A. Baffi, and S. Gaufres, "Gestion du parc d'équipements biomédicaux la piste de la géolocalisation," vol. 34 no. 3, pp. 70-77. [Online]. Available: https://linkinghub.elsevier.com/ retrieve/pii/S1959756813000205

[20] A. Dorri, S. S. Kanhere, and R. Jurdak, "Multi-agent systems: A survey," vol. 6, pp. 28573-28593.

[21] J. Oliveira, M. Jin, R. Lima, J. Kobza, and J. Montevechi, "The role of simulation and optimization methods in supply chain risk management: Performance and review standpoints," vol. 92, pp. 17-44. [Online]. Available: https://linkinghub.elsevier.com/retrieve/pii/ S1569190X18301734

[22] M. Anwar, "Digitalization in container terminal logistics : A literature review," pp. 1-25. [Online]. Available: http://urn.kb.se/resolve?urn=urn: nbn:se:bth-18482

[23] M. AHMED MOHAMED, C. Taconet, and M. OULD MOHAMED LEMINE, "La traçabilité dans les chaînes logistiques en utilisant l'IoT et la blockchain," in Evolution des SI : vers des SI Pervasifs ?, vol. 2019. Université Paris 1 Panthéon-Sorbonne, pp. 1-10. [Online]. Available: https://hal.archives-ouvertes.fr/hal-02152725

[24] Q. Schoen, D. Pinon-Baca, M. Lauras, F. Fontanili, and S. Truptil, "A new transport management system design considering the upcoming logistics environment and the sensitive products supply chains." [Online]. Available: https://hal-mines-albi.archives-ouvertes.fr/hal-01885901

[25] Solution : notre tracker | next4. [Online]. Available: https://next4.io/ solution-notre-tracker/

[26] Services. [Online]. Available: https://www.traxens.com/en/services

[27] Technologie de capteurs. [Online]. Available: https://www.dbschenker.com/fr-fr/produits/produits-sp\%C3\%A9ciaux/ technologie-de-capteurs-smartbox

[28] Shipping container monitoring | cargo security, location \& condition monitoring. [Online]. Available: https://arviem.com/ track-and-trace-container-tracking/

[29] Tetis. [Online]. Available: https://www.starcomsystems.com/tetis-fr/

[30] M. D. Sherwin, H. Medal, and S. A. Lapp, "Proactive cost-effective identification and mitigation of supply delay risks in a low volume 
high value supply chain using fault-tree analysis," vol. 175, pp. 153-163. [Online]. Available: http://www.sciencedirect.com/science/ article/pii/S0925527316000372

[31] L. Urciuoli, "An algorithm for improved ETAs estimations and potential impacts on supply chain decision making," vol. 25, pp. 185-193. [Online]. Available: https://linkinghub.elsevier.com/retrieve/pii/ S2351978918305924

[32] A. Mujumdar, P. S. Robi, M. Malik, and M. Horio, "Artificial neural network (ANN) model for prediction of mixing behavior of granular flows," vol. 8, no. 3, pp. 149-158. [Online]. Available: https://doi.org/10.1080/15502280701252495

[33] H. Mulyati and J. Geldermann, "Managing risks in the indonesian seaweed supply chain," vol. 19.

[34] S. Wattanakul, S. Henry, M. L. Bentaha, N. Reeveerakul, and Y. Ouzrout, "Improvement of the Containerize Performance based on the Unitary Traceability of Smart Logistics Units," in 15th IFIP International Conference on Product Lifecycle Management (PLM 2018), Torino, Italy, Jul. 2018. [Online]. Available: https: //hal.archives-ouvertes.fr/hal-01788465

[35] V. Mani, C. Delgado, B. Hazen, and P. Patel, "Mitigating supply chain risk via sustainability using big data analytics: Evidence from the manufacturing supply chain," Sustainability (Switzerland), vol. 9, no. 4, 2017.

[36] Y. Fan, L. Heilig, and S. Voß, "Supply chain risk management in the era of big data," Lecture Notes in Computer Science (including subseries Lecture Notes in Artificial Intelligence and Lecture Notes in Bioinformatics), vol. 9186, pp. 283-294, 2015.

[37] J. Tixier, G. Dusserre, O. Salvi, and D. Gaston, "Review of 62 risk analysis methodologies of industrial plants," vol. 15, no. 4 pp. 291-303. [Online]. Available: https://hal-ineris.archives-ouvertes.fr/ ineris-00961858

[38] S. Mokhtar, P. A. Bahri, S. Moayer, and A. James, "Supplier portfolio selection based on the monitoring of supply risk indicators," vol. 97 p. 101955. [Online]. Available: http://www.sciencedirect.com/science/ article/pii/S1569190X19300887

[39] M. Y. Samiri, "Impact de l'intégration du concept du produit intelligent sur la plateforme de la chaîne logistique du conteneur." [Online] Available: https://tel.archives-ouvertes.fr/tel-01735029

[40] Formal safety assessment. [Online]. Available: http://www.imo.org/fr/ OurWork/Safety/SafetyTopics/Pages/FormalSafetyAssessment.aspx

[41] H. S. Sii, T. Ruxton, and J. Wang, "A fuzzy-logic-based approach to qualitative safety modelling for marine systems," vol. 73, no. 1, pp. 19-34. [Online]. Available: http://www.sciencedirect.com/science/article/ pii/S0951832001000230

[42] A. Conca, A. D. Febbraro, D. Giglio, and F. Rebora, "Automation in freight port call process: real time data sharing to improve the stowage planning," vol. 30, pp. 70-79. [Online]. Available: http://www.sciencedirect.com/science/article/pii/S2352146518300802

[43] A. Serry and L. Lévêque, "Le système d'identification automatique (AIS). une source de données pour étudier la circulation maritime," no. 29, pp. 177-202. [Online]. Available: http://journals.openedition.org/netcom/1943

[44] Top 5 features to look for in a transportation management s. [Online]. Available: https://www.abivin.com/single-post/ Top-5-features-to-look-for-in-a-Transportation-Management-System-TMS

[45] M. Kärkkäinen, J. Holmström, K. Främling, and K. Artto, "Intelligent products - a step towards a more effective project delivery chain," pp. $141-151$.

[46] O. Ventä, Intelligent Products and Systems. Technology theme: Final report. VTT Technical Research Centre of Finland. [Online]. Available: https://cris.vtt.fi/en/publications/ intelligent-products-and-systems-technology-theme-final-report

[47] G. Baryannis, S. Validi, S. Dani, and G. Antoniou, "Supply chain risk management and artificial intelligence: state of the art and future research directions," International Journal of Production Research, vol. 57, no. 7, pp. 2179-2202, Apr. 2019. [Online]. Available: https://doi.org/10.1080/00207543.2018.1530476

[48] X. Zou, F. Tao, P. Jiang, S. Gu, K. Qiao, Y. Zuo, and L. Xu, "A new approach for data processing in supply chain network based on FPGA," vol. 84, no. 1, pp. 249-260. [Online]. Available: https://doi.org/10.1007/s00170-015-7803-x

[49] A. Andziulis, S. Jakovlev, D. Adomaitis, and D. Dzemydiene, "Integration of Mobile Control Systems into Intermodal Container Transportation Management," Transport, vol. 27, no. 1, pp. 40-48, Mar. 2012, wOS:000302499000005. 